\title{
Resistance in Capsicum pubescens to Xanthomonas campestris pv. vesicatoria Pepper Race 6
}

\author{
F. Sahin and S. A. Miller, Department of Plant Pathology, The Ohio State University, Ohio Agricultural Research \\ and Development Center, Wooster 44691
}

\begin{abstract}
Sahin, F., and Miller, S. A. 1998. Resistance in Capsicum pubescens to Xanthomonas campestris pv. vesicatoria pepper race 6. Plant Dis. 82:794-799.

One hundred seventy Capsicum spp. germplasm accessions were evaluated as potential sources of resistance to $X$. campestris pv. vesicatoria pepper race 6 (P6). This race has been identified recently in Ohio and overcomes all three known resistance genes in cultivated pepper. Only $C$. pubescens plant introduction (PI) 235047 was found to be resistant to X. campestris pv. vesicatoria P6 strains using hypersensitivity and pathogenicity tests. Further studies using PI 235047 as a differential line showed that strains classified as $X$. campestris pv. vesicatoria races $\mathrm{P} 1$ and $\mathrm{P} 3$ were heterogeneous in terms of virulence. Strains of $X$. campestris pv. vesicatoria $\mathrm{P} 1$ and $\mathrm{P} 3$ that were compatible with PI 235047 were reclassified as two new pepper races, designated $X$. campestris pv. vesicatoria $\mathrm{P} 7$ and $\mathrm{P} 8$, respectively. According to the new race classification, $\mathrm{PI}$ 235047 plants are incompatible with $X$. campestris pv. vesicatoria pepper races $\mathrm{P} 0, \mathrm{P} 1, \mathrm{P} 3, \mathrm{P} 4$, and $\mathrm{P} 6$, but compatible with races $\mathrm{P} 2, \mathrm{P} 5, \mathrm{P} 7$, and $\mathrm{P} 8$.
\end{abstract}

Bacterial spot of pepper (Capsicum spp.), caused by Xanthomonas campestris pv. vesicatoria (proposed to be renamed Xanthomonas axonopodis pv. vesicatoria; 37 ), is one of the most destructive pepper diseases both in the greenhouse and in the field when environmental conditions are favorable for the pathogen $(8,24,25,33)$. The current management methods for bacterial spot, including sanitation, chemical application, cultural practices, and use of $X$. campestris pv. vesicatoria-resistant cultivars $(10,14,17,23-25,27,29,33,36)$, are not always successful. Contaminated seeds are the main source of $X$. campestris $\mathrm{pv}$. vesicatoria inoculum $(3-5,17)$. However, seed treatment, which may not completely eliminate $X$. campestris pv. vesicatoria inoculum if internal seed infection occurs (5), is not always done, for economic reasons as well as potential reduction of seed viability. Cost, potential chemical residues on fruit, and resistance among X. campestris pv. vesicatoria strains are the main disadvantages of chemical applications $(2,27,29,33,36)$. Therefore, use of pepper cultivars resistant to $X$. campestris pv.

Corresponding author: S. A. Miller

E-mail address: miller.769@osu.edu

This research was supported by Ataturk University, Erzurum, Turkey, and State and Federal Funds appropriated to the Ohio Agricultural Research and Development Center (OARDC), The Ohio State University. OARDC Research Article Number 148-97.

Accepted for publication 24 March 1998.

Publication no. D-1998-0518-01R

(C) 1998 The American Phytopathological Society vesicatoria is economically and technically the most practical method for bacterial spot management (23-25). There is an increasing interest in developing pepper cultivars with resistance to bacterial spot. However, development of disease-resistant cultivars requires the identification and incorporation of resistance genes into horticulturally superior and widely acceptable cultivars. Good progress has been made in identification of suitable sources of disease resistance by screening a number of accessions of cultivated pepper species and related wild species with great genetic diversity $(11-13,15,16,20)$. So far, three genes for resistance to bacterial spot, designated $B s l$, $B s 2$, and $B s 3$, have been identified in three different plant introduction (PI) lines: PI 163192 (C. annuum), PI 260435 (C. chacoense), and PI 271322 (C. annuum), respectively $(11,13,20)$.

Resistance in pepper to strains of $X$. campestris pv. vesicatoria is associated with the hypersensitive response (HR; 1,69,11-13,15,16,18-21,28,30,34). Currently, seven pepper races (P0-P6) have been identified among $X$. campestris pv. vesicatoria strains worldwide $(8,22,28,29,32,33)$. Pepper races are easily identified based on the presence or absence of HR in the $X$. campestris pv. vesicatoria-susceptible cultivar Early Calwonder (ECW) and its near-isogenic derivative lines, designated ECW-10R, ECW-20R, and ECW-30R, which contain the resistance genes $B s l$, $B s 2$, and $B s 3$, respectively (28). Race P6 strains, first identified in Ohio in 1994 (32), are able to defeat all of the known resistance genes in pepper $(24,25,32,33)$. The number of $X$. campestris pv. vesicatoria P6 strains is increasing in Ohio and most of these are resistant to copper, streptomycin, or both (31). Therefore, new sources of resistance in pepper need to be identified.

The objectives of this study were to (i) evaluate Capsicum germplasm for sources of resistance to $X$. campestris pv. vesicatoria race $\mathrm{P} 6$ and (ii) utilize newly identified resistant pepper germplasm to determine the existence of additional variation in virulence among strains of other $X$. campestris pv. vesicatoria pepper races.

\section{MATERIALS AND METHODS}

Plant material and growing conditions. Seeds for all PI lines of Capsicum spp., including 119 accessions of $C$. annuum and 51 accessions of other Capsicum spp. (C. anomallum, C. baccatum, C. chacoense, C. chinense, $C$. frutescens, $C$. galapagoense, and $C$. pubescens) originating from 40 countries were obtained from the United States Department of AgricultureAgriculture Research Station (USDAARS) Plant Genetic Resources Conservation Unit, University of Georgia, Griffin (Table 1).

A total of 20 seeds from each of the 170 accessions and the bell pepper cultivar Marengo ( $X$. campestris pv. vesicatoriasusceptible) were sown in commercial peat mix (Baccto High Density Professional Planting Mix, Michigan Peat Co., Houston) in new 128-cell plastic flats (Landmark Plastics Corp., Akron, OH). The seedlings were grown on the greenhouse bench until they reached the second or third true-leaf stage (approximately 3 to 4 weeks). Then 15 seedlings of each accession were transplanted into five $25-\mathrm{cm}$ diameter plastic pots (three plants/pot) containing steamed soil (mixture of 0.43 $\mathrm{m}^{3}$ Wooster silty-loam, $0.43 \mathrm{~m}^{3}$ muck soil, $0.14 \mathrm{~m}^{3}$ peat moss, and $1.2 \mathrm{~kg}$ lime $/ \mathrm{m}^{3}$ ). The plants were maintained for 7 days in the greenhouse (20 to $28^{\circ} \mathrm{C}$ ) after transplanting. Plants were fertilized once a week with Peter's 20-20-20 (N-P-K; 454 $\mathrm{mg} / 378 \mathrm{ml}$ ) and watered as required. Nine plants from each accession were used to test pathogenicity and six plants were used to test HR elicitation. This experiment was conducted twice. The remaining five seedlings of the PI accessions and Marengo were used as negative controls in the experiments.

Inoculum preparation. A highly aggressive strain of $X$. campestris pv. vesicatoria pepper race $6, X$. campestris pv. 
vesicatoria $17 \mathrm{~b}$, isolated from pepper in 1994 in Ohio, was used. Strain X. campestris pv. vesicatoria $17 \mathrm{~b}$ was stored frozen $\left(-80^{\circ} \mathrm{C}\right)$ in $15 \%$ glycerol and recovered from frozen culture by restreaking onto yeast dextrose carbonate agar (YDC) medium (26) and incubating at $28^{\circ} \mathrm{C}$ for $48 \mathrm{~h}$. The bacteria were washed from the plate with a sterile glass spreader and suspended in sterile distilled water. The bacterial concentration was adjusted to approximately $10^{8} \mathrm{CFU} / \mathrm{ml}\left(A_{600 \mathrm{~nm}}=0.1\right)$. This concentration was used for inoculation and infiltration of pepper seedlings.

Plant inoculation. Nine 5-week-old pepper seedlings (three plants/pot) of each accession and Marengo were dipped into 4 liters bacterial suspension in a 5-liter plastic container. Five Marengo seedlings, dipped into sterilized distilled water, were used as a negative control in each experiment. The inoculated plants were arranged in a completely randomized design and incubated in a mist chamber at 90 to $95 \%$ relative humidity $(\mathrm{RH})$ for 3 days, then transferred to a greenhouse at 20 to $28^{\circ} \mathrm{C}$ for 7 days. The control plants were incubated under the same conditions, but in different greenhouses. The plants were observed for development of characteristic bacterial spot symptoms 10 days after inoculation. Plants were rated as positive or negative based on the presence or absence of disease symptoms. Pathogenicity was evaluated based on symptom development on Marengo. To test for elicitation of an $\mathrm{HR}$, a bacterial suspension $\left(10^{8} \mathrm{CFU} / \mathrm{ml}\right)$, prepared as described above, was infiltrated into the intercostal area of the leaves of two plants of each PI line and Marengo by using a 3-cc syringe (Becton Dickinson and Co., Franklin Lakes, NJ) without a hypodermic needle. Sterilized distilled water was infiltrated into the leaves of plants of all PI lines and Marengo as negative controls. The inoculated plants were arranged in a completely randomized design on the greenhouse bench and maintained for 24 to $48 \mathrm{~h}$ at 20 to $28^{\circ} \mathrm{C}$. The presence of rapid tissue necrosis at the inoculation site was recorded within 24 to $48 \mathrm{~h}$ after infiltration. This test was repeated at least three times.

Variation in host specificity, virulence and growth in plants. Seventy-two strains, including all of the known $X$. campestris pv. vesicatoria pepper races ( $\mathrm{P} 0$ to P6), were used. Strains V-19 and V-205, and strains 1138, 1140, and 1141 were obtained from D. F. Ritchie and F. Louws, respectively (Department of Plant Pathology, North Carolina State University, Raleigh). The remaining 67 strains were isolated from pepper or tomato plants collected from commercial fields in Ohio between 1993 and 1996. All strains were tested for HR elicitation on C. pubescens PI 235047, ECW, ECW-10R, ECW-20R, and ECW-30R as described above. The cultivar Marengo was used as a negative control. The results were recorded as positive or negative based on the presence or absence, respectively, of collapsed tissue at the inoculation site within $48 \mathrm{~h}$ after infiltration. This experiment was conducted four times.

Of the $72 X$. campestris pv. vesicatoria strains tested for HR on PI 235047, 58 were also tested for pathogenicity on this accession and Marengo. Two plants of each accession were dip-inoculated with individual strains as described above. Two plants of each line were dipped in sterile water as a negative control. The inoculated plants were arranged in a completely randomized design with two replications of a single plant each per experiment. The inoculated plants were incubated in a mist chamber at 90 to $95 \% \mathrm{RH}$ for 3 days, then transferred to the greenhouse at 20 to $28^{\circ} \mathrm{C}$ for 7 days. The plants were rated for disease severity 10 days after inoculation by using a scale of 1 to 5 , in which $1=$ no disease, 2 a few water-soaked lesions, 3 $=$ many spots with coalescence and slight plant wilting, $4=$ severe leaf defoliation, and 5 = plants dead. Average disease severity values (DSVs) for each of the bacterial strains on PI 235047 and Marengo plants were calculated from two experiments. The data were evaluated with analysis of variance (ANOVA), and differences among the treatment means were determined by calculating Fisher's least significant difference at $P=0.05$.

Table 1. Evaluation of Capsicum spp. accessions for resistance to Xanthomonas campestris pv. vesicatoria race P6

\begin{tabular}{|c|c|c|}
\hline Host/PI & HR $^{\mathbf{a}}$ & Disease $^{\mathrm{h}}$ \\
\hline \multicolumn{3}{|l|}{ Capsicum аппиит } \\
\hline \multicolumn{3}{|l|}{$102881,102882,102883,103048,105262,105444,105339,105538,109252,109254,109255,109469,123164,123165,123166$} \\
\hline \multirow{2}{*}{\multicolumn{3}{|c|}{$\begin{array}{l}123469,123470,123471,124080,124540,125801,125802,125803,127445,131352,135826,135873,135874,138557,138558, \\
138559\end{array}$}} \\
\hline & & \\
\hline \multicolumn{3}{|l|}{$164557,164558,164561,164562,164564,164565,164678,164961,167062,167100,167215,169102,169106,169110,169115}$, \\
\hline \multicolumn{3}{|l|}{ 169122, 169130, 169131, 169138, 176888, 181732, 181733, 181734, 182646, 184037, 184038, 184039, 187314, 187315, 187325, } \\
\hline \multicolumn{3}{|l|}{$188472,188473,188474,249907,249911,251622,257049,257187,262172,262905,263073,263074,263106,263110,264662$, } \\
\hline $267730,267731,267733,275008,275009,275011,281316,281323,281327,281330,281341,281400,281413,281416,286419$ & & \\
\hline $289762,291999,294452,297456,338490,338974,385960,385961,390436,390437,390970,390971,401728,401729$ & - & + \\
\hline \multicolumn{3}{|l|}{ C. annuum var. glabriusculum } \\
\hline $511885,511886,511887$ & - & + \\
\hline \multicolumn{3}{|l|}{ C. anomallum } \\
\hline 501532 & _ & + \\
\hline \multicolumn{3}{|l|}{ C. baccatum } \\
\hline $260434,273425,281398,3700004,3700005,413669,439359,439360,439361,439364,439369$ & _ & + \\
\hline \multicolumn{3}{|l|}{$\begin{array}{l}\text { C. baccatum var. baccatum } \\
\text { C. }\end{array}$} \\
\hline $215699,238061,260533,260567,281306$ & _- & + \\
\hline \multicolumn{3}{|l|}{ C. baccatum var. pendulum } \\
\hline $152217,152234,199506,203522,213915,224440,238062,241679,257122,241674,159235,188803$ & - & + \\
\hline \multicolumn{3}{|l|}{$\begin{array}{l}\text { C. baccatum var. praetermissum } \\
\text { S }\end{array}$} \\
\hline 260595 & - & + \\
\hline \multicolumn{3}{|l|}{ C. chacoense } \\
\hline $260426,260427,260430,260431,273429$ & - & + \\
\hline \multicolumn{3}{|l|}{ C. chinense } \\
\hline $152222,152225,152452,194879,200729,209589$ & - & + \\
\hline \multicolumn{3}{|l|}{$\begin{array}{l}\text { C. frutescens } \\
\text { lates }\end{array}$} \\
\hline $123474,159238,181865,188479$ & - & + \\
\hline \multicolumn{3}{|l|}{ C. galapagoense } \\
\hline G-1567 & _- & + \\
\hline \multicolumn{3}{|l|}{ C. pubescens } \\
\hline 235047 & + & _- \\
\hline 585266 & - & + \\
\hline
\end{tabular}

\footnotetext{
${ }^{\mathrm{a}} \mathrm{HR}=$ hypersensitive response; $-=$ HR not elicited; + = HR elicited.
}

${ }^{\mathrm{b}}$ Disease $=$ presence $(+)$ or absence $(-)$ of symptoms. 
Another experiment was conducted in the greenhouse to characterize disease resistance in $C$. pubescens PI 235047 plants to $X$. campestris pv. vesicatoria $\mathrm{P} 6$ strains based on bacterial population dynamics in inoculated leaves. Two plants each of PI 235047 and Marengo were inoculated separately with $X$. campestris pv. vesicatoria $17 \mathrm{~b}$ (race $\mathrm{P} 6$ ) and $X$. campestris pv. vesicatoria 116 (race $\mathrm{P} 1$ ), a virulent strain that did not elicit an HR on PI 235047. Inoculation, incubation, and disease assessment were done as described above. All of the leaves on two inoculated plants of each cultivar were collected after scoring disease severity. Half of the leaves were surface sterilized by dipping into 95\% EtOH, and the others were dipped into sterile distilled water. The leaves were

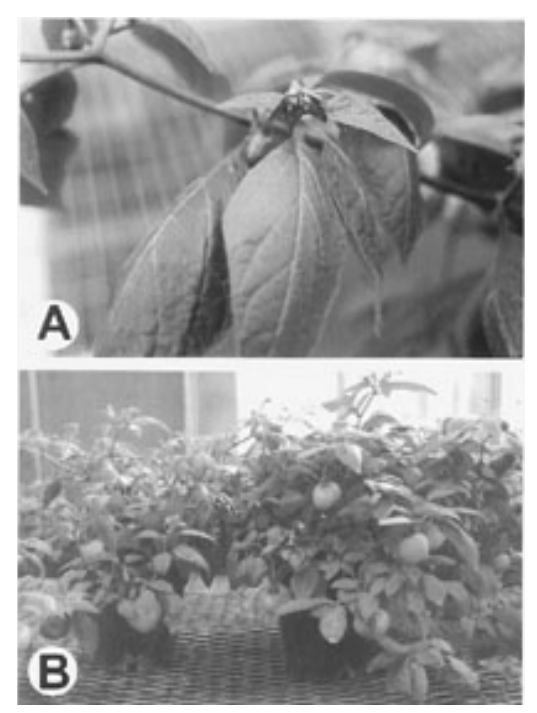

Fig. 1. Capsicum pubescens PI 235047 plants. (A) Flower (purple), (B) fruit (yellow).

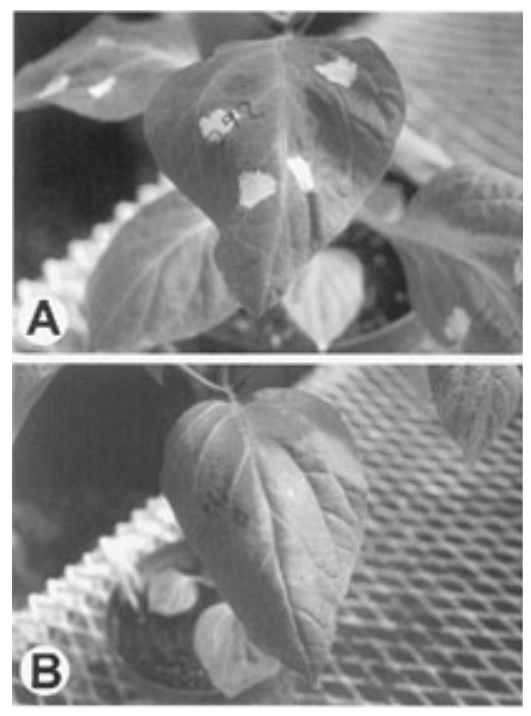

Fig. 2. Leaves of Capsicum pubescens PI 235047 plants infiltrated with a suspension of Xanthomonas campestris pv. vesicatoria (A) race P6 or (B) race P1. (A) Incompatible reaction, (B) compatible reaction. kept on paper towels for $30 \mathrm{~min}$ to allow the alcohol to evaporate. Then the leaf samples were macerated using a ball bearing tissue grinder (BioReba AG, Basel, Switzerland) in a separate plastic bag (Agdia Inc, Elkhorn, IN) containing $1 \mathrm{ml}$ sterile distilled water/g leaf tissue (fresh weight). Serial 10 -fold dilutions were performed in sterile distilled water and $0.1 \mathrm{ml}$ of the appropriate dilutions was spread onto each of two plates of CKTM medium (35). Characteristic X. campestris pv. vesicatoria colonies were counted after the plates were incubated for 4 days at $28^{\circ} \mathrm{C}$.

\section{RESULTS}

Characteristic symptoms of bacterial spot were observed on all Marengo plants, and all but one of the Capsicum spp. accessions inoculated with $X$. campestris pv. vesicatoria race $\mathrm{P} 6$, strain $17 \mathrm{~b}$. C. pubescens PI 235047 plants (Fig. 1) did not develop distinguishable symptoms of bacterial spot in either experiment (Table
1). The negative control Marengo plants inoculated with sterilized water also did not show any recognizable symptoms.

An HR to $X$. campestris pv. vesicatoria $17 \mathrm{~b}$ was elicited in all infiltrated leaves of PI 235047 plants within $24 \mathrm{~h}$ after inoculation (Table 1, Fig. 2). None of the other accessions or Marengo developed an HR during the 24 to $48-\mathrm{h}$ incubation period after infiltration. HR was not observed on leaves of $C$. pubescens PI 235047 or Marengo plants infiltrated with sterilized distilled water.

Variation in host specificity, virulence and growth in plants. Of the $72 \mathrm{X}$. campestris pv. vesicatoria strains tested, 46 (64\%) were race P3 (Table 2). The remaining strains were distributed as follows: 1 P0, 10 P1, 2 P2, 3 P4, 1 P5, and 10 P6. Although 41 strains (60\%) elicited an HR on C. pubescens PI 235047, the remaining 31 strains (40\%) were compatible. All strains of $X$. campestris pv. vesicatoria races $\mathrm{P} 0, \mathrm{P} 4$, and $\mathrm{P} 6$ and almost half of the $\mathrm{P} 1$ and P3 strains tested were incompati-

Table 2. Hypersensitive response (HR) in Capsicum pubescens PI 235047 plants and average disease severity (DSV) on PI 235047 and the pepper cultivar Marengo inoculated with strains of different pepper races of Xanthomonas campestris pv. vesicatoria

\begin{tabular}{|c|c|c|c|c|}
\hline \multirow[b]{2}{*}{ Strain $^{\mathbf{b}}$} & \multirow[b]{2}{*}{ Race $^{c}$} & \multirow[b]{2}{*}{ HR test ${ }^{\mathrm{d}}$} & \multicolumn{2}{|c|}{ DSV $^{\mathbf{a}}$} \\
\hline & & & PI 235047 & Marengo \\
\hline $\mathrm{V}-19$ & P0 & + & 1.00 & 2.75 \\
\hline Xcv-63 & $\mathrm{P} 1$ & + & 1.25 & 3.25 \\
\hline Xcv-118 & $\mathrm{P} 1$ & + & 1.00 & 3.50 \\
\hline Xcv-119a & $\mathrm{P} 1$ & + & 1.00 & 3.75 \\
\hline Xcv-119b & $\mathrm{P} 1$ & + & 1.25 & 4.00 \\
\hline Xcv-120 & $\mathrm{P} 1$ & + & 1.75 & 3.25 \\
\hline Xcv-106a & P3 & + & 1.75 & 3.75 \\
\hline Xcv-106b & P3 & + & 1.25 & 3.50 \\
\hline Xcv-107a & P3 & + & 1.00 & 2.75 \\
\hline Xcv-107b & P3 & + & 1.25 & 3.50 \\
\hline Xcv-108 & P3 & + & 1.00 & 3.75 \\
\hline Xcv-109a & P3 & + & 1.50 & 3.25 \\
\hline Xcv-109b & P3 & + & 1.50 & 3.50 \\
\hline Xcv-112 & P3 & + & 1.00 & 3.25 \\
\hline Xcv-113 & P3 & + & 1.75 & 2.75 \\
\hline Xcv-121 & P3 & + & 1.25 & 2.75 \\
\hline Xcv-122a & P3 & + & 1.00 & 3.50 \\
\hline Xcv-122b & $\mathrm{P} 3$ & + & 1.25 & 3.75 \\
\hline Xcv-122c & P3 & + & 1.25 & 3.50 \\
\hline Xcv-122d & P3 & + & 1.00 & 3.00 \\
\hline Xcv-127a & P3 & + & 1.25 & 3.75 \\
\hline Xcv-127b & P3 & + & 1.00 & 3.75 \\
\hline Xcv-127c & P3 & + & 1.25 & 3.25 \\
\hline Xcv-129a & P3 & + & 1.00 & 3.50 \\
\hline Xcv-129b & P3 & + & 1.00 & 4.00 \\
\hline Xcv-130 & P3 & + & 1.00 & 3.50 \\
\hline Xcv-794a & P3 & + & NT & NT \\
\hline Xcv-794b & P3 & + & NT & NT \\
\hline 1138 & $\mathrm{P} 4$ & + & NT & NT \\
\hline 1140 & $\mathrm{P} 4$ & + & NT & NT \\
\hline \multirow[t]{2}{*}{1141} & $\mathrm{P} 4$ & + & NT & NT \\
\hline & & & \multicolumn{2}{|c|}{ (continued on next page } \\
\hline
\end{tabular}

a Average disease severity values calculated from two experiments, each with two replications, after the plants were rated using a 1 to 5 scale where $1=$ no disease, $2=$ a few water-soaked lesions, $3=$ many spots with coalescence and slight plant wilting, $4=$ severe leaf defoliation, and $5=$ plants dead; NT $=$ not tested.

b Xanthomonas campestris pv. vesicatoria strains isolated from pepper or tomato.

${ }^{\mathrm{c}}$ Race of the $X$. campestris pv. Vesicatoria strains were determined by infiltration of bacterial suspension $\left(10^{8} \mathrm{CFU} / \mathrm{ml}\right)$ into the leaves of pepper differential lines.

d Strains of $X$. campestris pv. vesicatoria eliciting a hypersensitive response on PI 235047 plants; + = incompatible (resistant) reaction, $-=$ compatible (susceptible) reaction.

e ANOVA = analysis of variance; LSD = least significant difference. 
ble. All of the P2 and P5 strains were compatible on this accession.

All of the strains that elicited an HR (incompatible) on C. pubescens PI 235047 caused virtually no symptoms on PI 235047 plants after dip-inoculation. All of the $X$. campestris pv. vesicatoria strains that did not elicit an HR (compatible) on PI 235047 caused serious disease on PI 235047 plants. The average DSVs for PI 235047 plants inoculated with $X$. campestris pv. vesicatoria strains in the incompatible group (DSVs $=1$ to 1.75 ) were significantly $(P=0.05)$ less than those (DSVs $=2.25$ to 3.75) for plants inoculated with compatible strains (Table 2). Strains of $X$. campestris pv. vesicatoria in both groups caused serious disease on cultivar Marengo. While there were some significant differences between individual strains of $X$. campestris pv. vesicatoria in virulence on PI 235047 and Marengo, there were no differences between groups in virulence on Marengo (average DSVs for the compatible group $=3.5$, incompatible group $=3.42$ ). However, the DSVs of PI 235047 plants inoculated with compatible strains of $X$. campestris pv. vesicatoria (average DSV $=2.8$ ) were significantly less than those of Marengo plants (average $\mathrm{DSV}=3.5$ ) inoculated with these strains.

Without surface sterilization, the average density of $X$. campestris pv. vesicatoria 17b (P6) in PI 235047 leaves was $6 \times$ $10^{5} \mathrm{CFU} / \mathrm{g}$, significantly $(P=0.05)$ less than the bacterial density $\left(3.9 \times 10^{9}\right.$ $\mathrm{CFU} / \mathrm{g}$ ) in Marengo leaves. After surface sterilization, the average density of $X$. campestris pv. vesicatoria $17 \mathrm{~b}$ in $\mathrm{PI}$ 235047 leaves was $3.55 \times 10^{3} \mathrm{CFU} / \mathrm{g}$, also significantly less than in Marengo leaves $\left(7.2 \times 10^{7} \mathrm{CFU} / \mathrm{g}\right)$. The population density of $X$. campestris pv. vesicatoria $116(\mathrm{P} 1)$ in non-surface-disinfested PI 235047 and Marengo leaves was $1.4 \times 10^{8}$ and $5.9 \times$ $10^{8} \mathrm{CFU} / \mathrm{g}$, respectively. After surface disinfestation, the population density in PI 235047 leaves was $6.4 \times 10^{7} \mathrm{CFU} / \mathrm{g}$ and in Marengo leaves was $6.5 \times 10^{7} \mathrm{CFU} / \mathrm{g}$. These population densities did not differ significantly $(P=0.05)$.

\section{DISCUSSION}

Of the 170 accessions from eight different Capsicum species evaluated as potential sources of resistance to $X$. campestris

Table 2. (continued from preceding page)

\begin{tabular}{|c|c|c|c|c|}
\hline \multirow[b]{2}{*}{ Strain $^{b}$} & \multirow[b]{2}{*}{ Race $^{c}$} & \multirow[b]{2}{*}{ HR test ${ }^{\mathrm{d}}$} & \multicolumn{2}{|c|}{ DSV $^{a}$} \\
\hline & & & PI 235047 & Marengo \\
\hline Xcv-131b & P6 & + & NT & NT \\
\hline Xcv-787 & P6 & + & NT & NT \\
\hline Xcv-788 & P6 & + & NT & NT \\
\hline Xcv-789 & P6 & + & NT & NT \\
\hline Xcv-790 & P6 & + & NT & NT \\
\hline Xcv-791 & P6 & + & NT & NT \\
\hline Xcv-792 & P6 & + & NT & NT \\
\hline Xcv-793 & P6 & + & NT & NT \\
\hline Xcv-69 & P1 & - & 3.25 & 3.50 \\
\hline Xcv-114 & P1 & - & 3.25 & 4.00 \\
\hline Xcv-115 & P1 & - & 3.25 & 3.50 \\
\hline Xcv-116 & P1 & - & 3.75 & 3.75 \\
\hline Xcv-117 & P1 & - & 2.75 & 3.25 \\
\hline Xcv-66 & $\mathrm{P} 2$ & - & 2.25 & 4.00 \\
\hline Xcv-89 & P2 & - & 2.50 & 3.25 \\
\hline Xcv-90 & P3 & - & 2.50 & 3.25 \\
\hline Xcv-91 & P3 & - & 2.75 & 3.75 \\
\hline Xcv-110a & P3 & - & 3.25 & 3.75 \\
\hline $\mathrm{Xcv}-110 \mathrm{~b}$ & P3 & - & 2.75 & 3.75 \\
\hline Xcv-110c & P3 & - & 2.25 & 3.25 \\
\hline Xcv-111 & P3 & - & 3.00 & 3.75 \\
\hline Xcv-123a & P3 & - & 2.75 & 3.50 \\
\hline $\mathrm{Xcv}-123 \mathrm{~b}$ & P3 & - & 3.25 & 2.75 \\
\hline $\mathrm{Xcv}-123 \mathrm{c}$ & P3 & - & 2.75 & 3.25 \\
\hline Xcv-123d & P3 & - & 2.25 & 2.75 \\
\hline Xcv-124a & P3 & - & 2.75 & 3.25 \\
\hline $\mathrm{Xcv}-124 \mathrm{~b}$ & P3 & - & 3.00 & 3.00 \\
\hline $\mathrm{Xcv}-124 \mathrm{c}$ & P3 & - & 3.00 & 3.75 \\
\hline Xcv-124d & P3 & - & 3.25 & 3.25 \\
\hline Xcv-124e & P3 & - & 2.75 & 3.00 \\
\hline Xcv-125a & P3 & - & 2.75 & 4.00 \\
\hline Xcv-126a & P3 & - & 2.25 & 3.75 \\
\hline Xcv-126b & P3 & - & 2.75 & 4.00 \\
\hline Xcv-128a & P3 & - & 2.50 & 4.00 \\
\hline Xcv-128b & P3 & - & 3.00 & 3.50 \\
\hline $\mathrm{Xcv}-128 \mathrm{c}$ & P3 & - & 2.25 & 3.25 \\
\hline $\mathrm{Xcv}-128 \mathrm{~d}$ & P3 & - & 2.50 & 3.50 \\
\hline Xcv-767 & P3 & - & NT & NT \\
\hline V-205 & P5 & - & 3.25 & 3.75 \\
\hline $\operatorname{ANOVA}^{\mathrm{e}}(P=0.05)$ & & & $\mathrm{LSD}=0.17$ & $\mathrm{LSD}=0.20$ \\
\hline
\end{tabular}

pv. vesicatoria P6 strains, only C. pubescens PI 235047 was resistant. None of the C. pubescens PI 235047 plants tested showed leaf spot symptoms 10 days after inoculation, while other accessions and Marengo plants were highly susceptible. Furthermore, elicitation of HR was observed in C. pubescens PI 235047 plants within $24 \mathrm{~h}$ after infiltration, but not in other PI lines or Marengo plants. This supports evidence from previous studies $(13,15,16,20)$ that there is a strong correlation between the incompatible interaction of $X$. campestris pv. vesicatoria strains on pepper and HR elicitation, which can be used as a method for screening Capsicum accessions for resistance to the bacterial spot pathogen. In addition, these results indicate that $C$. pubescens PI 235047 plants carry a resistance $(\mathrm{R})$ gene or genes that presumably correspond to a novel (unknown) avirulence gene or genes in $X$. campestris pv. vesicatoria P6 strains. Although genetic analyses of resistance in $C$. pubescens PI 235047 and avirulence in $X$. campestris pv. vesicatoria $\mathrm{P} 6$ strains have not been done, it is likely that the resistance is governed by a single gene, which we propose to designate $B s 4$, with the corresponding avirulence gene in the pathogen designated avrBs4. Our results, demonstrating a qualitative response to the pathogen and the presence of an HR in PI 235047 plants infiltrated with $X$. campestris pv. vesicatoria $\mathrm{P} 6$ strains, provide indirect evidence for single-gene resistance to bacterial spot in this accession. Furthermore, all three previously identified bacterial spot resistance genes in pepper, $B s l$, $B s 2$, and $B s 3$, are single dominant genes $(11,13,15,16,20)$. Genetic studies are needed to determine the inheritance of resistance to bacterial spot in this new resistance source.

Further evaluation of variation in virulence among $X$. campestris pv. vesicatoria pepper races showed that $C$. pubescens PI 235047 plants are not only incompatible with $X$. campestris pv. vesicatoria P6 strains, but also with $\mathrm{P} 0, \mathrm{P} 4$, and half of the $\mathrm{P} 1$ and $\mathrm{P} 3$ strains tested. The diversity among $X$. campestris pv. vesicatoria $\mathrm{P} 1$ and P3 strains provided evidence that the strains within $X$. campestris pv. vesicatoria pepper races may not be homogeneous in terms of host specificity and virulence. Although pathological diversity among strains of $X$. campestris pv. vesicatoria pepper races $\mathrm{P} 0$, $\mathrm{P} 2, \mathrm{P} 4, \mathrm{P} 5$, and P6 was not observed, this does not necessarily indicate that the strains within these races were homogeneous, because the number of strains tested was limited. In order to discriminate different pathogenic groups within $X$. campestris pv. vesicatoria races, C. pubescens PI 235047 was used as an additional pepper differential line. Therefore, $X$. campestris pv. vesicatoria strains were reclassified into races based on HR on pepper differential lines including PI 235047 (Table 3). 
Two new $X$. campestris pv. vesicatoria pepper races, designated $X$. campestris pv. vesicatoria $\mathrm{P} 7$ and $\mathrm{P} 8$, were identified by splitting from $X$. campestris pv. vesicatoria race $\mathrm{P} 1$ and $\mathrm{P} 3$, the strains that were compatible with PI 235047. Based on the new race classification of $X$. campestris pv. vesicatoria strains, $C$. pubescens PI 235047 plants are incompatible with strains of $X$. campestris pv. vesicatoria pepper races $\mathrm{P} 0, \mathrm{P} 1, \mathrm{P} 3, \mathrm{P} 4$, and $\mathrm{P} 6$. However, they are compatible with strains of $X$. campestris pv. vesicatoria pepper races $\mathrm{P} 2$, $\mathrm{P} 5, \mathrm{P} 7$, and P8.

The disease severity data showed that $C$. pubescens PI 235047 plants are significantly less susceptible than Marengo plants to $X$. campestris pv. vesicatoria strains that do not elicit an HR in PI 235047. These results suggest that $C$. pubescens PI 235047 plants may also provide a source of quantitative resistance to $X$. campestris pv. vesicatoria races $\mathrm{P} 2, \mathrm{P} 5, \mathrm{P} 7$, and $\mathrm{P} 8$.

Surface sterilization of inoculated pepper leaves caused at least a 10-fold reduction in average bacterial population densities, suggesting that $X$. campestris pv. vesicatoria applied during inoculation may survive on leaf surfaces for a long time. Therefore, the bacterial counts determined directly from dilution plating without surface disinfestation may not represent the internal bacterial densities or be correlated with the disease severity values of the inoculated leaves.

The finding of a new resistance source in C. pubescens PI 235047 to X. campestris pv. vesicatoria has several implications. The gene or genes responsible for resistance to race P6 may be incorporated into commercial pepper cultivars to provide protection against an emerging problem. It may also be possible to transfer apparent quantitative resistance as well. Although crossing barriers between purple-flowered (C. pubescens) and white-flowered (including $C$. annuum, $C$. baccatum, $C$. chinense, and $C$. frutescens) pepper species are known, barriers between $C$. pubescens and $C$. annuum can be overcome by using bridge pepper species such as $C$. cardenasii or $C$. eximium (38). Furthermore, this new resistance source may allow molecular

Table 3. Proposed race classification of Xanthomonas campestris pv. vesicatoria pepper strains based on hypersensitive reaction (HR) on pepper differential lines and Capsicum pubescens PI 235047

\begin{tabular}{|c|c|c|c|c|c|}
\hline \multirow[b]{2}{*}{ Races } & \multicolumn{5}{|c|}{ Pepper differential lines } \\
\hline & ECW & ECW-10R BsI & ECW-20R Bs2 & ECW-30R Bs3 & PI $235047 B s 4^{\text {a }}$ \\
\hline$\overline{\mathrm{P} 0}$ & $\mathrm{-}^{\mathrm{b}}$ & HR & HR & HR & HR \\
\hline P1 & - & - & HR & HR & HR \\
\hline P2 & - & HR & HR & - & - \\
\hline P3 & - & - & HR & - & HR \\
\hline P4 & - & - & - & HR & HR \\
\hline P5 & - & HR & - & - & - \\
\hline P6 & - & - & - & - & HR \\
\hline P7 & - & - & HR & HR & - \\
\hline P8 & - & - & HR & - & - \\
\hline
\end{tabular}

\footnotetext{
a Proposed designation.
}

${ }^{\mathrm{b}}$ Compatible interaction.

characterization of additional resistance genes in Capsicum spp. and avirulence genes in $X$. campestris pv. vesicatoria.

\section{ACKNOWLEDGMENTS}

We thank L. V. Madden and P. E. Lipps for providing pre-submission reviews, and M. S. Krause for preparation of the figures.

\section{LITERATURE CITED}

1. Adamson, W. C., and Grover, S. Jr. 1983. Inheritance of bacterial spot resistance in pepper. HortScience 18:905-906.

2. Adaskaveg, J. E., and Hine, R. B. 1985. Copper tolerance and zinc sensitivity of Mexican strains of Xanthomonas campestris pv. vesicatoria, causal agent of bacterial spot of pepper. Plant Dis. 69:993-996.

3. Bashan, Y., Diab, S., and Okon, Y. 1982. Survival of Xanthomonas campestris pv. vesicatoria in pepper seeds and roots in symptomless and dry leaves in non-host plants and in the soil. Plant Soil 68:161-170.

4. Bashan, Y., and Okon, Y. 1986. Internal and external infections of fruits and seeds of pepper by Xanthomonas campestris pv. vesicatoria. Can. J. Bot. 64:2865-2871.

5. Bashan, Y., Okon, Y., and Henis, Y. 1982. Long-term survival of Pseudomonas syringae pv. tomato and Xanthomonas campestris pv. vesicatoria in tomato and pepper seeds. Phytopathology 72:1143-1144.

6. Bonas U., Schulte, R., Fenselau, S., Minsavage, G. V., Staskawicz, B. J., and Stall, R. E. 1991. Isolation of a gene cluster from Xanthomonas campestris pv. vesicatoria that determines pathogenicity and the hypersensitive response on pepper and tomato. Mol. PlantMicrobe Interact. 4:81-88.

7. Bonas, U., Stall, R. E., and Stasckawicz, B. J. 1989. Genetic and structural characterization of the avirulence gene avrBs 3 from Xanthomonas campestris pv. vesicatoria. Mol. Gen. Genet. 218:127-136.

8. Bouzar, H., Jones, J. B., Stall, R. E., Hodge, N. C., Minsavage, G. V., Benedict, A. A., and Alvarez, A. M. 1994. Physiological, chemical, serological, and pathogenic analyses of a worldwide collection of Xanthomonas campestris pv. vesicatoria strains. Phytopathology 84:663-671.

9. Canteros, B., Minsavage, G., Bonas U., Pring, D., and Stall, R. 1991. A gene from Xanthomonas campestris pv. vesicatoria that determines avirulence in tomato is related to avrBs3. Mol. Plant-Microbe Interact. 4:628632.

10. Conover, R. A., and Gerhold, N. R. 1981. Mixtures of copper and maneb or mancozeb for control of bacterial spot of tomato and their compatibility for control of fungus diseases. Proc. Fla. State Hortic. Soc. 94:154156.

798 Plant Disease / Vol. 82 No. 7
11. Cook, A. A., and Guevara, Y. G. 1984. Hypersensitivity in Capsicum chacoense to race 1 of the bacterial spot pathogen of pepper. Plant Dis. 68:329-330.

12. Cook, A. A., and Stall, R. E. 1963. Inheritance of resistance in pepper to bacterial spot. Phytopathology 53:1060-1062.

13. Cook, A. A., and Stall, R. E. 1982. Distribution of races of Xanthomonas vesicatoria pathogenic on pepper. Plant Dis. 66:388389.

14. Cox, R. S. 1982. Control of bacterial spot of tomato in southern Florida. Plant Dis. 66:870.

15. Hibberd, A. M., Bassett, M. J., and Stall, R. E. 1987. Allelism tests of three dominant genes for hypersensitive resistance to bacterial spot of pepper. Phytopathology 77:1304-1307.

16. Hibberd, A. M., Stall, R. E., and Bassett, M.J. 1987. Different phenotypes associated with incompatible races and resistance genes in bacterial spot disease of pepper. Plant Dis. 71:1075-1078.

17. Jones, J. B., Pohronezny, K. L., Stall, R. E., and Jones, J. P. 1986. Survival of Xanthomonas campestris pv. vesicatoria in Florida on tomato crop residue, weeds, seeds, and volunteer tomato plants. Phytopathology 76:430-434.

18. Kearney, B., Ronald, P. C., Dahlbeck, D., and Staskawicz, B. J. 1988. Molecular basis for evasion of plant host defence in bacterial spot disease of pepper. Nature 332:541-543.

19. Keen, N. T. 1990. Gene-for-gene complementarity in plant-pathogen interactions. Annu. Rev. Genet. 24:447-463.

20. Kim, B.-S., and Hartmann, R. W. 1985. Inheritance of a gene $(B s 3)$ conferring hypersensitive resistance to Xanthomonas campestris pv. vesicatoria in pepper (Capsicum апnиum). Plant Dis. 69:233-235.

21. Knoop, V., Staskawicz, B., and Bonas, U. 1991. Expression of avirulence gene avrBs3 from Xanthomonas campestris pv. vesicatoria is not under the control of hrp genes and is independent of plant factors. J. Bacteriol. 173:7142-7150.

22. Kousik, C. S., and Ritchie, D. F. 1995. Isolation of pepper races 4 and 5 of Xanthomonas campestris pv. vesicatoria from diseased peppers in southern U. S. fields. Plant Dis. 79:540

23. Kousik, C. S., and Ritchie, D. F. 1996. Evaluation of bell pepper varieties against races 1-4 of the bacterial spot pathogen, 1995. Biol. Cult. Tests Plant Dis. Control 11:97.

24. Kousik, C. S., and Ritchie, D. F. 1996. Disease potential of pepper bacterial spot pathogen races that overcome the $B s 2$ gene for resistance. Phytopathology 86:1336-1343.

25. Kousik, C. S., and Ritchie, D. F. 1996. Mixed genotypes combined with copper sprays to manage bacterial spot of bell peppers. Phytopathology 86:502-508.

26. Lelliot, R. A., and Stead, D. E. 1987. Methods for the diagnosis of bacterial diseases of plants. Blackwell Scientific Publications, Oxford.

27. Marco, G. M., and Stall, R. E. 1983. Control of bacterial spot of pepper initiated by strains of Xanthomonas campestris pv. vesicatoria that differ in sensitivity to copper. Plant Dis. 67:779-781.

28. Minsavage, G. V., Dahlbeck, D., Whalen, M. C., Kearney, B., Bonas, U., Staskawicz, B. J., and Stall, R. E. 1990. Gene for gene relationships specifying disease resistance in Xanthomonas campestris pv. vesicatoria-pepper interactions. Mol. Plant-Microbe Interact. 3:41-47.

29. Ritchie, D. F., and Dittapongpitch., V. 1991. Copper- and streptomycin-resistant strains and host differentiated races of Xanthomonas 
campestris pv. vesicatoria in North Carolina. Plant Dis. 75:733-736.

30. Ronald, P. C., and Staskawicz, B. J. 1988. The avirulence gene avrBs1 from Xanthomonas campestris pv. vesicatoria encodes a $50-\mathrm{kd}$ protein. Mol. Plant-Microbe Interact. 1:191198.

31. Sahin, F. 1997. Detection, identification and characterization of strains of Xanthomonas campestris pv. vesicatoria by traditional and molecular methods, and resistance in Capsicum species to Xanthomonas campestris pv. vesicatoria pepper race 6. Ph.D. thesis. The Ohio State University, Columbus.
32. Sahin, F., and Miller, S. A. 1995. First report of pepper race 6 of Xanthomonas campestris pv. vesicatoria, causal agent of bacterial spot of pepper. Plant Dis. 79:1188.

33. Sahin, F., and Miller, S. A. 1995. Characterization of Ohio strains of Xanthomonas campestris pv. vesicatoria, causal agent of bacterial spot of pepper. Plant Dis. 80:773-778.

34. Schulte, R., and Bonas, U. 1992. Expression of the Xanthomonas campestris pv. vesicatoria hrp gene cluster, which determines pathogenicity and hypersensitivity on pepper and tomato, is plant inducible. J. Bacteriol. 174:815-823.

35. Sijam, K., Chang, C. J., and Gitaitis, R. D.
1991. An agar medium for the isolation and identification of Xanthomonas campestris pv. vesicatoria from seed. Phytopathology 81:831-834.

36. Stall, R. E., and Thayer, P. L. 1962. Streptomycin resistance of the bacterial spot pathogen and control with streptomycin. Plant Dis. Rep. 46:389-392.

37. Vauterin, L., Hoste, B., Kersters, K., and Swings, J. 1995. Reclassification of Xanthomonas. Int. J. Syst. Bacteriol. 45:472-489.

38. Zijlstra, S., Purimahua, C., and Lindhout, P. 1991. Pollen tube growth in interspecific crosses between Capsicum species. HortScience 26:585-586. 